\title{
English for Specific Purposes in Palestinian Context: Determining EFL Cadets' Needs at Al Istiqlal University
}

\author{
Hussam Ahmed Qaddomi \\ Al Istiqlal University, Jericho, Palestine
}

\begin{abstract}
This study aimed at determining EFL cadets' needs at Al-Istiqlal University in Palestine. In addition, the study sought to reveal how cadets rated their own competence in particular skills in EFL, and what they really need from their EFL course. The study was conducted on a random sample of 91 cadets. The findings showed that Al-Istiqlal University cadets' level in EFL is intermediate as the total score mean was 3.4 (68.0\%). Also, results showed that cadets' needs of EFL gained a very important level where its mean was 3.67 (73.4 \%). Moreover, results indicated that the most serious difficulty which faces the cadets, as they perceive future workplace, in learning EFL is following English conversations. In addition, results revealed that there were significant differences in AU cadets EFL needs on all domains in favor of Police Sciences, Military Sciences, and MIS over the Psychology Security due to major variable.
\end{abstract}

Index Terms-EFL, needs analysis, ESP, cadets, major

\section{INTRODUCTION}

Developing language skills and curriculum especially in English for Specific Purposes (ESP) context often begins with identifying how syllabus design can address the specific needs of learners (Ali and Salih, 2013; Basturkmen, 2006; Bedjaoui and Allal, 2012; Brown, 1995; Bosher \& Smalkowski, 2002; Chan, 2001; Chaudron et al., 2005; Chostelidou, 2010; Cowling, 2007; Gatehouse, 2001; Martinez-Pons, 2001; Singh, 2005; Soruc, 2012; Valdez, 1999). Learners are the ones who are directly involved in the teaching- learning process and who also play crucial roles in shaping the outcomes and contents of the course. As such, their perceptions of their needs can provide valuable information for programs directors and planners to shape the curriculum development that bases the content of language courses on the communication needs, wants and interests of the learners (Akyela and Ozeka, 2010; Igawa, 2007; Kusumoto; 2008; Long, 2005; Spence and Liu, 2013; Tsao, 2011). The learners are often viewed as the best judges of their own needs because they know what they can and cannot do with the target language; and what language skills are most essential especially when they are going to work in security agencies or peacekeeping forces as the case of the Palestinian service men and women who study at Al Istiqlal University. No study has been conducted to determine or to respond to the cadets EFL needs and to decide the content of the English programs that are relevant to the cadets' academic study and future careers. So as to identify the English language needs of Al Istiqlal University cadets and to inform the syllabus rationalization and curriculum renewal of the English language courses, such study was necessitated investigation.

The problem of the study sufficed as at all universities in Palestine, EFL has been studied as a General English (GE) course. There is no university across Palestine which is interested in teaching English for Special Purposes (ESP) especially English for security purposes. Al- Istiqlal University teaches one English course, and no study has been conducted since the establishment of the university to determine the cadets' needs of learning EFL or developing further ESP courses. The present study, therefore, emanates from the need to investigate the English language needs of $\mathrm{Al}$ Istiqlal University cadets who are going to be officers serving in the various sectors of the Ministry of the Interior in Palestine. However, hardly any studies on Palestinian cadets' needs of EFL have been conducted. The current study tried to address the following questions:

1. What is the perceived current level of English as Foreign Language of Al-Istiqlal University cadets?

2. To what extent are English language basic skills (listening, speaking, reading and writing) needed in cadets' future workplace?

3. What are the cadets' needs of English language in the workplace: aspects of difficulties?

4. What is the importance of English for job performance, promotion, and personal life?

The present study tested the following hypothesis:

There are no significant differences in Al-Istiqlal University cadets' needs of EFL due to major variable.

This study was limited to the cadets at Al Istiqlal University in the academic year 2012. The significance of the study is mainly concerned with cadets who will study what they really want not what is being imposed on them. The syllabus designers to develop it based on the cadets' concerns and wants. This research aimed to investigate the current EFL level of cadets as they perceive themselves, EFL skills needed in cadets' future workplace, AU cadets' English language difficulties, and the importance of English for job performance, promotion, and personal life of AU cadets. 


\section{LITERATURE REVIEW AND RELATED STUDIES}

ESP focuses on the students' needs and implies a wide variety of resources of language (Dudley-Evans, 1998; Robinson, 1980). Strevens (1988) (cited in Gatehouse, 2001) mentioned characteristics of ESP:

a. Absolute characteristics:

ESP consists of teaching English language to meet the language needs of specific areas, jobs, discourse, semantics in syntax, lexis.

b. Variables characteristics:

Strevens (1988) mentioned variables characteristics of "ESP may be, but is not necessarily restricted as to the language skills to be learned... taught according to any pre-ordained methodology..." (p. 1-2).

According to Munby (1978) ESP, the concept of "needs analysis" is manipulated in different ways depending on learners' wants of language, and the actual needs of learners. Mackay and Mountford in 1978 suggested three purposes of ESP. Learners need it as for profession, e.g. the need for use in military, law enforcement...etc. The vocational training program purpose includes hotel and catering staff ... etc. Academic or professional study is another purpose of ESP e.g., the engineering, medicine, law... etc. Robinson (1991) argued that ESP language should suit for the profession, communicative, effective and not be necessarily native-speaker like. Khamkaew (2009), added to develop language curriculum, needs analysis would be the first step. NA involves investigating and collecting information about learners' needs, analyzing these needs, and then decides what inclusions should be in courses based on interpretation so as to fulfill the needs of learners. Brown (1995) added that teachers and planners are responsible for determining the learners' language needs so as to design an effective teaching course. However, there is no conscious on a definition of needs analysis. Richard and Platt (1992) as cited in Al-Harby, (2005 p. 15-16) added that the definition of 'needs' depends on the perception of those making the judgment (Ali and Salih, 2013 p.12).

Analyzing learners' needs is a reliable way to designers to foster effective curriculum (Akyela and Ozek, 2010; Benesch, 1996; Lockwood, 2012). Richards (2001) added that a needs assessment guarantees a flexible, modifiable curriculum rather than ridged, linear curriculum that is designed in advance by teachers (Idris, et al., 2007).

During the last thirty three years there have been a huge number of studies that attempted to analyze the learners' vocational or academic needs. In a study conducted by Abo Mosallem (1984) determined the needs of Egyptian Police officers in learning English language. A sample consisted of 150 police officers who work in different police departments in Egypt. Results showed that the police identified the officers' need for English. In terms of skills priority, the study showed that speaking and listening were given the highest priority. However, International Police Department rated reading and writing skills as in high priority. In terms of relevance of English to workplace, $83.2 \%$ of the working officers expressed their beliefs that English will help them do better work performance; 16.8 percent of the officers felt that English language learning contribute greatly to personal development.

Al-Gorashi (1989) cited in (Alhuqbani, 2008) investigated the Saudi military cadets English communicative needs at King Abdul Aziz Military Academy. A questionnaire was developed and distributed to 212 officers. The findings revealed that English is very important in situations related to the cadets' future work and their training courses such as the principles and techniques of parachute operation for Infantry officers. It was found that all officers indicated the necessity for the language skills such as listening skills and reading skills than speaking skills or writing skills. Akyel and Yalcin (1991) conducted a study on the Turkish policemen to determine their learning needs. The policemen reported that learning to listen and to speak in language is more necessary than to read or to write to their profession and workplace. They also indicated that they prefer to study language curricula which contain input data from their subject areas. The analysis of the language learning needs of Turkish policemen led to the adoption of several cognitive/affective principles in the writing process of the course materials. First, the materials should be authentic and interesting. Second, as motivation is a key factor, they should motivate learners to take active role and interact in the language learning process. Third, such principles should help learners improve their communication skills. Al-Huneidi and Basturkmen (1996) studied Kuwait University students' and faculty needs to learn English language. Also, they examined their perceptions of the importance of skills, sub-skills, and language deficiencies; language demands and needs. Perceptions of University of Kuwait students and faculty members differed concerning necessity of learning read and to listen and areas of difficulty and specific tasks important for study; the relevance of the institutions' current English second language program was assessed. It was found that over $60 \%$ faculty members perceived students to have inadequate skills.

Ketkaew (1997) carried out a study to determine the English language needs of cabin attendants. Many domains were investigated in this study such as: English language needs the functional aspects of English, English language usage problems, and determining the needs to develop the English language skills of cabin attendants. As results revealed, English language gained high importance to all cabin crew including: air stewards, air stewardesses, air pursers and flight managers in Thai Airways International. The study also indicated that the most needed skills were English language listening and speaking skills. The respondents also indicated the problems associated with using the English language four skills were moderate for all of them. The most English language skills that were needed to be improved as reported by Air stewards and air stewardesses were listening and speaking skills, however air pursers and flight managers reported that they need to develop all four skills from moderate to high levels. 
Dooey (2006) identified the listening and speaking needs of international students at Curtin University in her NA and included both ESL instructors and students in the study. The perceptions of students and instructors differed to some degree but they agreed on the importance of listening for academic success and attributed importance to general listening skills in lectures, tutorial and group assignments and areas of difficulty were also identified. Alhuqbani (2008) in his study attempted to identify police officers' needs of mastering English language in the Kingdom of Saudi Arabia. For this purpose the researcher developed a questionnaire and administered it to 103 serving police officers. The results showed that English language captures an integral part in security and police jobs. All participants identified skills which were very important to their workplace as important. The results also showed that despite the importance of English for the security sectors and officers, no training on EFL has been carried out on how to use English for police purposes. Generally, results confirmed that English for police purposes should be emphasized.

Khamkaew (2009) investigated the Metropolitan Police Officers' (MPOs) needs and problems in English language listening and speaking skills who work at Chana Songkram Police Station. A questionnaire and the interview administered to 30 metropolitan police officers. Results revealed that EL listening and speaking skills should be improved in "greeting and offering help, asking for personal details and problems and wants, giving information about accommodation, tourist information, transportation, emergency calls, giving directions, and giving advice and instruction in safety, travel, and shopping" (p. 37). Most MPOs expressed the need of good command of English in listening and speaking. On the other hand, the main problems associated to speaking were using expressions, producing full sentences, and the pronunciation of vowel sounds. Chen (2009) examined The Republic of China Military Academy cadets' difficulties in speaking English. The researcher used five open-ended questions. Questions focused on cadets' difficulties in speaking English, how often they used and practiced English, how to improve their speaking ability on their own, as well as any suggested comments. The results indicated that the most difficult aspect of speaking for the cadets were not confident enough and afraid of making mistakes while speaking, fluency, and lacking sufficient vocabulary. The researcher mentioned that the reasons for these difficulties were mostly not practicing enough. Regarding the helpful ways, cadets felt that more authentic English input and listen more, read more and read aloud more are to be included in their training.

Al-Tamimi and Shuib (2010) studied students' EFL needs at Hadhramout University of Science and Technology in the academic year 2006-2007. The study sought to determine the frequent use of English language skills, their importance, ability in using the skills, the needed training in the areas of language, and their English language course preferred. A total sample of 81 third, fourth, and final-year petroleum were selected to do Needs Analysis. The study emphasized the importance of English language for students and determined the students' needs, wants and necessities of English.

Khushi and Talaat (2011) evaluated the ELT textbooks designed for the Pakistan Military Academy (PMA), Kakul. The main purpose of this study was to identify the pedagogic value of the book. Results showed that the syllabus is traditional in approach. The choice of any language teaching content should suit context where it will be taught. Such alignment between textbook content and students' language needs will be a motivating factor for learners and provokes achievement. The study clarified that content related specific/general is needed instead of many literature in the course.

Spence and Liu (2013) conducted a study implemented needs analysis questionnaires online and semi-structured interview questions to investigate engineers English language needs at company of semiconductor manufacturing in Taiwan. Results showed that engineers face a large number of English communicative situations such as: writing and reading emails, reports, and memos. On the other hand, other situations associated with oral functions such as: meetings, teleconferences, and presentations. Results revealed that there is a growing increase for the need for English especially where oral skills being in used with customer visits and relationship building. Khushi (2012) carried out a study sought to investigate the academic and professional English needs of military cadets from the teacher' perceptions, the study also aimed to contribute to the development of a course of English for Military Purposes. The researcher used the interview as an instrument administered to 12 EL instructors. Findings revealed that English Language plays an integral part of military cadets' academic and professional lives. The results also showed that speaking and writing were more important than reading and listening.

\section{METHODOLOGY}

\section{Population}

The population of this study consisted of 500 male and female cadets.

Sample

The study sample consisted of 91 cadets. Tables 1 and 2 show the distribution.

TABLE 1:

\begin{tabular}{l|ll}
\multicolumn{2}{c}{ SAMPLE DISTRIBUTION ACCORDING TO GENDER } \\
Gender & Frequency & Percentages \\
\hline Male & 60 & 65.9 \\
Female & 31 & 34.1 \\
\hline Total & $\mathbf{9 1}$ & $\mathbf{1 0 0 \%}$
\end{tabular}


TABLE 2:

\begin{tabular}{l|ll}
\multicolumn{2}{c}{ SAMPLE DISTRIBUTION ACCORDING TO MAJOR } \\
Major & Frequency & Percentages \\
\hline Police Sciences & 34 & 37.4 \\
Military Sciences & 18 & 19.8 \\
\hline Psychology Security & 20 & 22.0 \\
MIS & 19 & 20.8 \\
\hline Total & 91 & $100 \%$
\end{tabular}

\section{Instrumentation}

The researcher used a five - point Likert scale questionnaire. Also, the researcher adapted some items of Alhuqbani's questionnaire (2008) and modified them to suit the study.

Validity of the questionnaire

The researcher distributed the questionnaire to a jury who are specialized in TEFL. The content was reviewed and most of them agreed that the questionnaire suits the purposes of the study.

Reliability of the questionnaire

Crombach Alpha Formula was implemented to establish the reliability of the questionnaire where it gained a score of (0.96).

TABLE 3

RELIABILITY OF THE QUESTIONNAIRE ACCORDING TO THE DOMAINS

\begin{tabular}{llll}
\hline No & Domains & Items & Reliability \\
1 & Perceived level in EFL & 0.85 & 4 \\
2 & EFL skills importance in workplace & 0.79 & 4 \\
3 & English language listening skill & 0.80 & 5 \\
4 & English language speaking skill & 0.67 & 4 \\
5 & English language reading skill & 0.70 & 3 \\
6 & English language writing skill & 0.81 & 4 \\
7 & English structures & 0.82 & 4 \\
8 & Using English in workplace & 0.83 & 4 \\
9 & The importance of English in promotion and performance & 0.87 & 9 \\
10 & Using English in security tasks & 0.92 & 16 \\
& Total & $\mathbf{0 . 9 6}$ & $\mathbf{5 7}$ \\
\hline
\end{tabular}

\section{FINDINGS AND DisCUSSION}

The first question that the study tried to answer is what is the EFL current level of Al-Istiqlal University cadets as they perceive themselves? To answer such question, means, percentages and SD were used. Table (4) shows the results.

TABLE 4

MEANS, PERCENTAGES AND STANDARD DEVIATIONS OF THE FIRST DOMAIN (PERCEIVED OVERALL LEVEL OF EFL OF AL-ISTIQLAL UNIVERSITY CADETS)

\begin{tabular}{l|llll}
$\mathbf{5}$ & \multicolumn{1}{c}{ (PERCEIVED OVERALL LEVEL OF EFL OF AL-ISTIQLAL UNIVERSITY CADETS) } \\
No. & Domain & Means & Percentage & Level \\
\hline $\mathbf{1}$ & Listening comprehension & 3.52 & 70.4 & Good \\
$\mathbf{2}$ & Speaking (Conversation) & 2.75 & 55.0 & Beginner \\
\hline $\mathbf{3}$ & Reading & 3.74 & 74.8 & Good \\
$\mathbf{4}$ & Writing & 3.59 & 71.8 & Good \\
\hline & Total score & 3.40 & 68 & Moderate
\end{tabular}

It is pretty obvious, that Al-Istiqlal University cadets' level in EFL is intermediate as the total score mean was 3.4 $(68.0 \%)$. It can be inferred from the results above that AU cadets' level in EFL not good in the speaking skill. Such results are due to the fact that English language is still not used in daily life conversation. In addition, teaching listening and speaking skills are almost neglected by English teachers. This result confirms with Abu- Zahra and Shayeb (2011). To identify the cadets' perceptions of EFL importance in their work, the study answered the following question:

To what extent are English language skills (listening, speaking, reading and writing) needed in cadets' future workplace? Table 5 shows the results.

TABLE 5

MEANS, STANDARD DEVIATIONS AND PERCENTAGES OF EFL SKILLS IMPORTANCE

\begin{tabular}{l|llll}
\multicolumn{5}{c}{ MEANS, STANDARD DEVIATIONS AND PERCENTAGES OF EFL SKILLS IMPORTANCE } \\
N0. & Domain & Means & Percentage & Level \\
\hline $\mathbf{1}$ & Listening comprehension & 3.70 & 74.0 & Very important \\
$\mathbf{2}$ & Speaking (Conversation) & 4.03 & 80.6 & Very important \\
\hline $\mathbf{3}$ & Reading & 3.47 & 69.4 & Very important \\
$\mathbf{4}$ & Writing & 3.46 & 69.2 & Very important \\
\hline & Total score & $\mathbf{3 . 6 7}$ & $\mathbf{7 3 . 4}$ & Very important
\end{tabular}


Table 5 shows that the total score of cadets' needs of EFL gained a very important level where its mean was 3.67 $(73.4 \%)$. This reveals that AU cadets are very aware of the importance of EFL in their workplace. A similar result was indicated in Al Gorashi's study (1989).

To determine which skill cadets really need, their perceptions were tested to decide which skill is essential for them. Regarding the priority of EFL skills, it is clear that cadets need listening and speaking (Akyel and Yalcin, 1991) as the means show above.

To what extent cadets need the receptive and productive skills in English for security work?

To answer such question means, SDs and percentages were calculated. Such results are clear in table 6, 7, 8 and 9.

Listening skill:

TABLE 6

\begin{tabular}{|c|c|c|c|c|}
\hline No. & Item & Means & Percentage & Level \\
\hline 1 & $\begin{array}{l}\text { I need listening to understand terms and scripts } \\
\text { associated with security such as theft, robbery, alibi... }\end{array}$ & 3.93 & 78.6 & Very important \\
\hline 2 & $\begin{array}{l}\text { I need listening to understand scripts and expressions in } \\
\text { general. }\end{array}$ & 3.72 & 74.4 & Very important \\
\hline 3 & $\begin{array}{l}\text { I need listening to understand different accents like BE } \\
\text { and } \mathrm{AE} \text {. }\end{array}$ & 3.49 & 69.8 & Very important \\
\hline 4 & $\begin{array}{l}\text { I need listening to understand courses in the fields of } \\
\text { security, military and police. }\end{array}$ & 3.82 & 76.4 & Very important \\
\hline \multirow[t]{2}{*}{5} & $\begin{array}{l}\text { I need listening to understand inquires and questions } \\
\text { foreigners ask about my work. }\end{array}$ & 3.79 & 75.8 & Very important \\
\hline & Total score & 3.75 & 75.0 & Very important \\
\hline
\end{tabular}

It is apparent that the degree of cadets' needs to master listening skill is very important as its mean was $3.75(75.0 \%)$. As can be clearly induced from the above percentages, AU cadets need to develop the skill of listening for many purposes i.e., understanding the British and American accents, to understand seminars or courses in the fields of security, military and police, and understand inquires and questions foreigners ask about my work. Such results are consistent with Al- Gorashi's (1989); Akyel \& Yalcin (1991); and Al- Huneidi \& Basturkman (1996) and Suwanla-Ong (1999) concluded that listening and speaking skills were the most important to master.

Speaking skill:

TABLE 7

\begin{tabular}{|c|c|c|c|c|}
\hline No. & Item & Means & Percentage & Level \\
\hline 1 & $\begin{array}{l}\text { I need speaking skill and conversation to use terms and } \\
\text { expressions associated with security work. }\end{array}$ & 4.0 & 80.0 & Very important \\
\hline 2 & I need to speak general English. & 3.3 & 66.0 & Important \\
\hline 3 & $\begin{array}{l}\text { I need to speak English because I want to understand } \\
\text { what foreigners say about my agency. }\end{array}$ & 4.0 & 80.0 & Very important \\
\hline \multirow[t]{2}{*}{4} & $\begin{array}{l}\text { I need to speak English so as to discuss topics related to } \\
\text { security, TV interviews, conferences or pamphlets. }\end{array}$ & 3.91 & 78.2 & Very important \\
\hline & Total score & 3.78 & 75.6 & Very important \\
\hline
\end{tabular}

Table 7 shows that the total score of speaking and conversation domain in English for security work is ranked as very important where its mean is $3.78(75.6 \%)$. It can be indicated that AU cadets clearly identify their needs of learning the speaking. Cadets stated that speaking skill is very important since it helps them to use terms and expressions associated with security work, to understand what foreigners say about their agency and to discuss topics associated with their job. The cadets' ranking is consistent with the findings of Abo Mosallem(1984); Akyel \& Yalcin (1991); Abdel Ghany \& Abdel Latif (2012). In ESP course, it is generally believed that the Communicative Language Teaching (CLT) suits ESP courses (Hutchinson \& Waters, 1987).

Reading skill:

TABLE 8

MEANS STANDARD DEVIATIONS AND PERCENTAGES OF READING DOMAIN IN ENGLISH FOR SECURITY WORK

\begin{tabular}{|c|c|c|c|c|}
\hline No. & Item & Means & Percentage & Level \\
\hline 1 & $\begin{array}{l}\text { I need reading to correctly read and understand } \\
\text { security-related words and terminology related to my } \\
\text { job. }\end{array}$ & 3.82 & 76.4 & Very important \\
\hline 2 & $\begin{array}{l}\text { I need reading to correctly read, translate and } \\
\text { understand materials related to my job. }\end{array}$ & 3.67 & 73.4 & $\begin{array}{l}\text { Very } \\
\text { Important }\end{array}$ \\
\hline 3 & $\begin{array}{l}\text { I need reading to correctly read and understand general } \\
\text { words, phrases, and non-related security, military and } \\
\text { police texts. }\end{array}$ & 3.29 & 65.8 & Important \\
\hline & Total score & 3.59 & 71.8 & Very important \\
\hline
\end{tabular}


The reading in English domain ranked as a very important one where the mean is 3.59 (71.8\%). This is because cadets need to acquire terms associated with their majors, to understand and translate texts relevant to their specialization especially what is published about their job. Results confirm with Al-Jurf (1994).

Writing skill:

TABLE 9

\begin{tabular}{|c|c|c|c|c|}
\hline N0. & Item & Means & Percentage & Level \\
\hline 1 & $\begin{array}{l}\text { I need writing to correctly write reports related to my } \\
\text { job. }\end{array}$ & 3.73 & 74.6 & Very Important \\
\hline 2 & $\begin{array}{l}\text { I need writing to correctly write an article in a } \\
\text { security related journal or magazine when doing a } \\
\text { staff course. }\end{array}$ & 3.48 & 69.6 & $\begin{array}{l}\text { Very } \\
\text { Important }\end{array}$ \\
\hline 3 & $\begin{array}{l}\text { I need writing to correctly write a briefing relevant to } \\
\text { my job. }\end{array}$ & 3.52 & 70.4 & Very important \\
\hline \multirow[t]{2}{*}{4} & $\begin{array}{l}\text { I need writing to correctly write short essays on } \\
\text { general topics. }\end{array}$ & 3.20 & 64.0 & Important \\
\hline & Total score & 3.48 & 69.6 & Very Important \\
\hline
\end{tabular}

As can be seen from the table writing domain ranked as a very important one where the mean is $3.48(69.6 \%)$. Some cadets indicated that they need writing to I need writing to correctly write reports related to my job. Other cadets reported that writing is important because they need it to correctly write an article in a security related journal or magazine when doing a staff course.

What are the cadets' needs of English language grammar?

TABLE 10

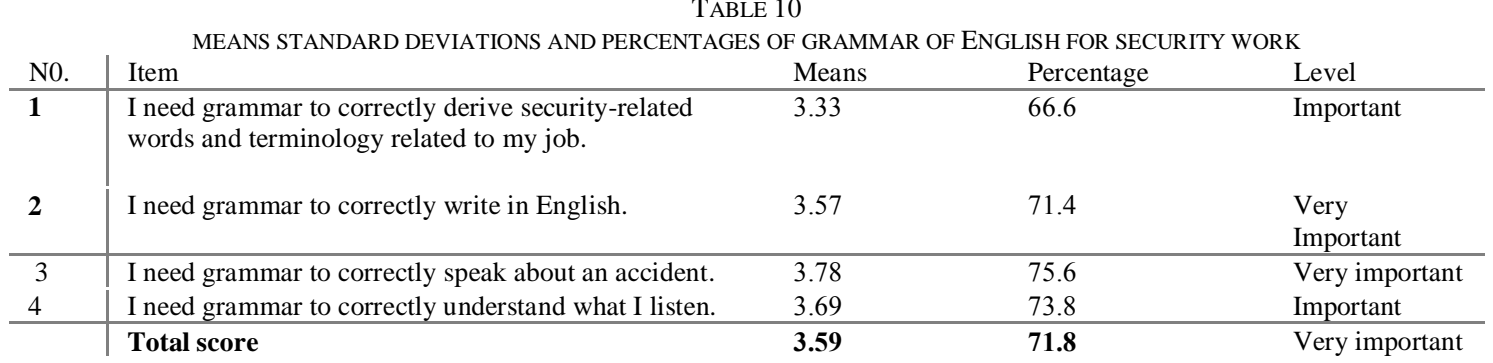

It is obvious that cadets need to learn and use English grammar is, as the rest of the skills, very important since it ranked 3.59 (71.8\%). Like the rest of the English language skills, cadets do not neglect the importance of grammar in learning English because such language area helps them a lot in correctly derive security-related words and terminology related to their job. In addition, grammar, as they perceive it, helps them to correctly write in English and understand what they listen or speak.

What are the cadets' needs of English language in the workplace: aspects of difficulties? To answer this question, means, SDs and percentages were used.

TABLE 11

MEANS, STANDARD DEVIATIONS AND PERCENTAGES OF ENGLISH LANGUAGE IN THE ASPECTS OF DIFFICULTIES

\begin{tabular}{|c|c|c|c|c|}
\hline No. & Item & Means & Percentage & Level \\
\hline 1 & $\begin{array}{l}\text { I find difficulty in following English conversations of natural } \\
\text { speed. }\end{array}$ & 3.77 & 75.4 & $\begin{array}{l}\text { very } \\
\text { high }\end{array}$ \\
\hline 2 & $\begin{array}{l}\text { I find difficulty in communicating } \\
\text { in English with foreigners of different dialects . }\end{array}$ & 3.62 & 72.4 & $\begin{array}{l}\text { very } \\
\text { high }\end{array}$ \\
\hline 3 & $\begin{array}{l}\text { I find difficulty in understanding } \\
\text { all that is said in English. }\end{array}$ & 3.24 & 64.8 & $\begin{array}{l}\text { very } \\
\text { high }\end{array}$ \\
\hline \multirow[t]{2}{*}{4} & $\begin{array}{l}\text { I find difficulty in using English } \\
\text { because of cultural differences. }\end{array}$ & 3.49 & 69.8 & $\begin{array}{l}\text { very } \\
\text { high }\end{array}$ \\
\hline & Total score & 3.53 & 70.5 & $\begin{array}{l}\text { very } \\
\text { high }\end{array}$ \\
\hline
\end{tabular}

Table 11 summarizes the cadets' responses to the aspects of difficulties that they may encounter in the future workplace. These results are considered as dangerous indications. The most serious difficulty which faces the cadets, as they perceive future workplace, in learning EFL is following English conversations. This result because teaching conversation and speaking skills is overlooked. Similar results were found in Abo Mosallem's (1984) and Khamkaew (2009).

What is the importance of English for job performance, promotion, and personal life? To answer this question, means, SDs and percentages were used. 
TABLE 12

\begin{tabular}{|c|c|c|c|c|}
\hline N0. & Item & Means & Percentage & Level \\
\hline 1 & $\begin{array}{l}\text { Knowledge of English helps me in: } \\
\text { Performing my job effectively. }\end{array}$ & 3.84 & 76.8 & Very important \\
\hline 2 & Passing my training courses. & 4.10 & 82.0 & Very important \\
\hline 3 & Passing military examinations. & 3.71 & 74.2 & Very important \\
\hline 4 & Increasing my knowledge in my field of specialization and work. & 3.13 & 62.6 & Important \\
\hline 5 & Promoting me to a higher military rank. & 3.14 & 62.8 & Important \\
\hline 6 & Raising my monthly salary. & 3.90 & 78.0 & Very important \\
\hline 7 & Advancing my study in an English-speaking country. & 3.97 & 79.4 & Very important \\
\hline 8 & $\begin{array}{l}\text { Increasing my chances to receive a scholarship to pursue my } \\
\text { graduate study or to engage in training courses in an English } \\
\text { speaking country. }\end{array}$ & 3.85 & 77.0 & Very important \\
\hline \multirow[t]{2}{*}{9} & $\begin{array}{l}\text { Conversing with people who can speak English but not Arabic, } \\
\text { in the various fields of life such as hospitals and shopping } \\
\text { centers. }\end{array}$ & 3.90 & 78.0 & Very important \\
\hline & Total score & 3.73 & 74.6 & Very important \\
\hline
\end{tabular}

It is clear that the total score of this domain reached a very important rank where its mean was 3.73 and its percentage was 74.6\%. Cadets at Al-Istiqlal University were asked to give their opinion about the importance of English for job performance, promotion, and personal life. Table 12 clearly shows that almost all the participants indicated that knowledge of English is essential to their work.

The study sought to determine what types of tasks in which English may be used.

TABLE 13

SHOWS THE RESULTS OF MEANS, STANDARD DEVIATIONS AND PERCENTAGES OF TYPES OF TASKS IN WHICH ENGLISH MAY BE USED

\begin{tabular}{|c|c|c|c|c|}
\hline No. & Item & Means & Percentage & Response \\
\hline 1 & $\begin{array}{l}\text { Knowledge of EFL is important to obtain information } \\
\text { passport holders identities. }\end{array}$ & 4.00 & 80.0 & $\begin{array}{l}\text { Very } \\
\text { important }\end{array}$ \\
\hline 2 & $\begin{array}{l}\text { Discussing issues related to arrival and departure of } \\
\text { foreigners from the official viewpoint. }\end{array}$ & 3.91 & 78.2 & $\begin{array}{l}\text { Very } \\
\text { important }\end{array}$ \\
\hline 3 & Filling out official forms through answering questions. & 3.74 & 74.8 & $\begin{array}{l}\text { Very } \\
\text { important }\end{array}$ \\
\hline 4 & Providing data about registering and residency. & 3.70 & 74.0 & $\begin{array}{l}\text { Very } \\
\text { important }\end{array}$ \\
\hline 5 & $\begin{array}{l}\text { Providing data about the place, job hours, and bank systems, } \\
\text { money exchangers, and accommodation. }\end{array}$ & 3.53 & 70.6 & $\begin{array}{l}\text { Very } \\
\text { important }\end{array}$ \\
\hline 6 & $\begin{array}{l}\text { Investigating accidents and taking data about place and cause } \\
\text { of accidents and kinds of injuries. }\end{array}$ & 3.65 & 73.0 & $\begin{array}{l}\text { Very } \\
\text { important }\end{array}$ \\
\hline 7 & $\begin{array}{l}\text { Making telephone conversations with people ask for help in } \\
\text { traffic context, problems and offering assistance. }\end{array}$ & 3.75 & 75.0 & $\begin{array}{l}\text { Very } \\
\text { important }\end{array}$ \\
\hline 8 & $\begin{array}{l}\text { Conducting driving license tests as asking and answering } \\
\text { questions to understand and describe road signs. }\end{array}$ & 3.66 & 73.2 & $\begin{array}{l}\text { Very } \\
\text { important }\end{array}$ \\
\hline 9 & $\begin{array}{l}\text { interpreting rules about } \\
\text { importing and exporting goods } \\
\text { and regulations of journeys ticket holders. }\end{array}$ & 3.51 & 70.2 & $\begin{array}{l}\text { Very } \\
\text { important }\end{array}$ \\
\hline 10 & $\begin{array}{l}\text { Questioning about missings to obtain data about the } \\
\text { description, value, and circumstances of losing such } \\
\text { items. }\end{array}$ & 3.49 & 69.8 & $\begin{array}{l}\text { Very } \\
\text { important }\end{array}$ \\
\hline 11 & $\begin{array}{l}\text { Investigating common breaches and crimes in which } \\
\text { foreigners are involved (e.g., burglary, robbery, Pick } \\
\text { pocketing, and sex crimes). }\end{array}$ & 3.71 & 74.2 & $\begin{array}{l}\text { Very } \\
\text { important }\end{array}$ \\
\hline 12 & $\begin{array}{l}\text { Discussing crime related issues such as: crime motives, } \\
\text { denying, contradicting and } \\
\text { confirming statements. }\end{array}$ & 3.46 & 69.2 & $\begin{array}{l}\text { Very } \\
\text { important }\end{array}$ \\
\hline 13 & Discussing alibis of a suspect. & 3.41 & 68.2 & $\begin{array}{l}\text { Very } \\
\text { important }\end{array}$ \\
\hline 14 & Identifying people according to description. & 3.48 & 69.6 & $\begin{array}{l}\text { Very } \\
\text { important }\end{array}$ \\
\hline 15 & $\begin{array}{l}\text { Obtaining data about the physical description of missing } \\
\text { people. }\end{array}$ & 3.76 & 75.2 & $\begin{array}{l}\text { Very } \\
\text { important }\end{array}$ \\
\hline \multirow[t]{2}{*}{16} & $\begin{array}{l}\text { Supervising and coordinating with foreign advisers in } \\
\text { security, military and police work. }\end{array}$ & 3.76 & 75.2 & $\begin{array}{l}\text { Very } \\
\text { Important }\end{array}$ \\
\hline & Total score & 3.66 & 73.2 & $\begin{array}{l}\text { Very } \\
\text { important }\end{array}$ \\
\hline
\end{tabular}

Table 12 shows that the total score of this domain reached a very important rank where its mean was 3.66 and its percentage was $73.2 \%$. It is very clear from the table above that cadet' responses to the situations where they need to use English support the conclusion of (Hutchinson and Waters, 1987; Robinson, 1991; and Long, 2005). 
The hypothesis says that there are no significant differences in Al-Istiqlal University cadets' needs of EFL due to major variable.

To test such hypothesis the researcher used One- ANOVA and tables 13 and 14 show the results.

TABLE 13

\begin{tabular}{|c|c|c|c|c|}
\hline Domains & \multicolumn{2}{|c|}{ RESULTS RELATED TO THE MAJOR VARIABLE } & Means & SDs \\
\hline \multirow{2}{*}{ 1. Perceived level in EFL } & Military Sciences & 18 & 3.60 & 0.97 \\
\hline & MIS & 19 & 3.80 & 0.76 \\
\hline \multirow{5}{*}{ 2. EFL skills importance in workplace } & Total & 91 & 3.40 & 0.94 \\
\hline & Police Sciences & 34 & 3.79 & 0.58 \\
\hline & Psychology Security & 20 & 3.10 & 1.04 \\
\hline & MIS & 19 & 4.00 & 0.68 \\
\hline & Total & 91 & 3.67 & 0.80 \\
\hline \multirow[t]{3}{*}{ 3. English language listening skill } & Police Sciences & 34 & 3.90 & 0.66 \\
\hline & Military Sciences & 18 & 3.90 & 0.79 \\
\hline & Psychology Security & 20 & 3.40 & 1.06 \\
\hline \multirow{4}{*}{ 4. English language speaking skill } & Military Sciences & 18 & 4.00 & 0.72 \\
\hline & Psychology Security & 20 & 3.39 & 1.12 \\
\hline & MIS & 19 & 3.80 & 0.63 \\
\hline & Total & 91 & 3.80 & 0.79 \\
\hline \multirow[t]{4}{*}{ 5. English language reading skill } & Police Sciences & 34 & 3.60 & 0.84 \\
\hline & Military Sciences & 18 & 3.90 & 0.72 \\
\hline & Psychology Security & 20 & 3.20 & 0.99 \\
\hline & MIS & 19 & 3.70 & 0.59 \\
\hline \multirow{3}{*}{ 6. English language writing skill } & Total & 91 & 3.60 & 0.83 \\
\hline & Police Sciences & 34 & 3.60 & 0.79 \\
\hline & Military Sciences & 18 & 3.90 & 0.78 \\
\hline \multirow{6}{*}{ 8. Using English in workplace } & Total & 91 & 3.60 & 0.95 \\
\hline & Police Sciences & 34 & 3.80 & 0.97 \\
\hline & Military Sciences & 18 & 3.70 & 0.89 \\
\hline & Psychology Security & 20 & 3.10 & 1.20 \\
\hline & MIS & 19 & 3.30 & 0.89 \\
\hline & Total & 91 & 3.50 & 1.02 \\
\hline \multirow{4}{*}{$\begin{array}{l}\text { 9. The importance of English in } \\
\text { promotion and performance }\end{array}$} & Police Sciences & 34 & 4.00 & 0.61 \\
\hline & Military Sciences & 18 & 3.90 & 0.63 \\
\hline & Psychology Security & 20 & 3.10 & 1.02 \\
\hline & MIS & 19 & 3.60 & 0.68 \\
\hline \multirow{6}{*}{ 10. Using English in security tasks } & Total & 91 & 3.70 & 0.79 \\
\hline & Police Sciences & 34 & 3.90 & 0.65 \\
\hline & Military Sciences & 18 & 3.80 & 0.75 \\
\hline & Psychology Security & 20 & 3.10 & 0.82 \\
\hline & MIS & 19 & 3.60 & 0.65 \\
\hline & Total & 91 & 3.70 & 0.76 \\
\hline \multirow{5}{*}{ Total Score } & Police Sciences & 34 & 3.90 & 0.80 \\
\hline & Military Sciences & 18 & 3.80 & 0.84 \\
\hline & Psychology Security & 20 & 3.00 & 0.68 \\
\hline & MIS & 19 & 3.70 & 0.74 \\
\hline & Total & 91 & 3.60 & 0.85 \\
\hline
\end{tabular}


TABLE 14

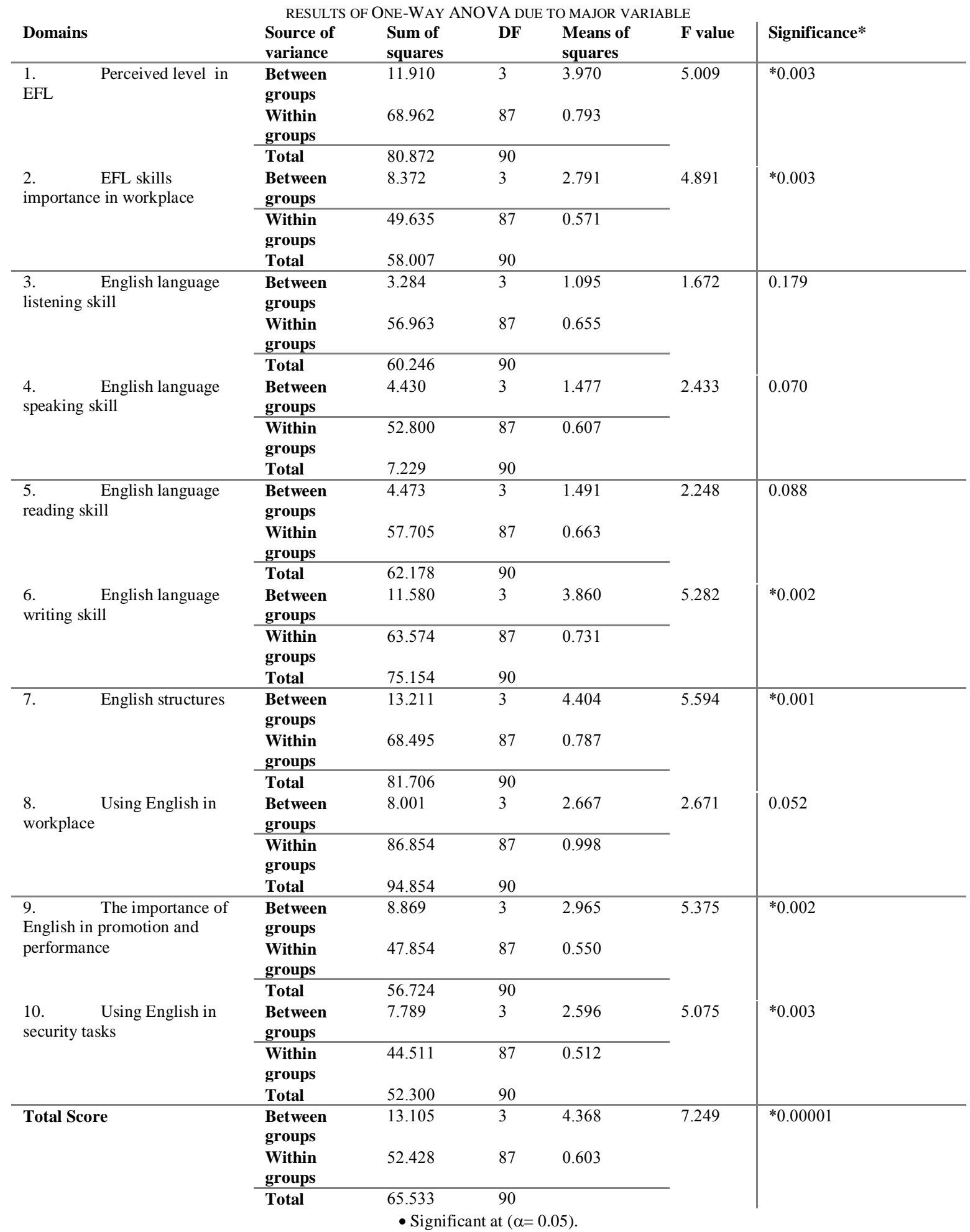

Table 14 shows that there were no significant differences at $(\alpha=0.05)$ on the third domain, the forth domain, the fifth domain and eighth domain; whereas there were significant differences on the first domain, the sixth domain, the seventh domain, the ninth domain, the tenth domain and the total score.

To determine among which the differences were, Scheffe Post Hoc was implemented. 
TABLE 15

\begin{tabular}{|c|c|c|c|c|c|}
\hline Domain & Major & $\begin{array}{l}\text { Police } \\
\text { sciences }\end{array}$ & $\begin{array}{l}\text { Military } \\
\text { sciences }\end{array}$ & $\begin{array}{l}\text { Psychology } \\
\text { security }\end{array}$ & MIS \\
\hline \multirow[t]{3}{*}{ Perceived level in EFL } & Police sciences & & $0.2279-$ & 0.6096 & $0.4319-$ \\
\hline & Military sciences & & & $* 0.8375$ & $0.2039-$ \\
\hline & $\begin{array}{l}\text { Psychology security } \\
\text { MIS }\end{array}$ & & & & $* 1.0414$ \\
\hline \multirow[t]{3}{*}{ EFL skills importance } & Police sciences & & 0.1201 & $* 0.6493$ & $0.2264-$ \\
\hline & Military sciences & & & 0.5292 & $0.3465-$ \\
\hline & $\begin{array}{l}\text { Psychology security } \\
\text { MIS }\end{array}$ & & & & $* 0.8757$ \\
\hline Domain & Major & $\begin{array}{l}\text { Police } \\
\text { sciences }\end{array}$ & $\begin{array}{l}\text { Military } \\
\text { sciences }\end{array}$ & $\begin{array}{l}\text { Psychology } \\
\text { security }\end{array}$ & MIS \\
\hline \multirow{3}{*}{$\begin{array}{l}\text { English language } \\
\text { writing skill }\end{array}$} & Police sciences & & $0.3137-$ & $* 0.7404$ & 0.1029 \\
\hline & Military sciences & & & $* 1.0542$ & 0.4167 \\
\hline & $\begin{array}{l}\text { Psychology security } \\
\text { MIS }\end{array}$ & & & & $0.6375-$ \\
\hline \multirow[t]{3}{*}{ English structures } & Police sciences & & $0.3350-$ & 0.6581 & $0.3649-$ \\
\hline & Military sciences & & & $* 0.9931$ & $0.02997-$ \\
\hline & $\begin{array}{l}\text { Psychology security } \\
\text { MIS }\end{array}$ & & & & $* 1.0230$ \\
\hline \multirow{3}{*}{$\begin{array}{l}\text { The importance of } \\
\text { English in promotion } \\
\text { and performance }\end{array}$} & Police sciences & & 0.0704 & $* 0.7958$ & 0.3586 \\
\hline & Military sciences & & & $* 0.7253$ & 0.2882 \\
\hline & $\begin{array}{l}\text { Psychology security } \\
\text { MIS }\end{array}$ & & & & $0.4371-$ \\
\hline \multirow{3}{*}{$\begin{array}{l}\text { Using English in } \\
\text { security tasks }\end{array}$} & Police sciences & & 0.0588 & $* 0.7432$ & 0.3368 \\
\hline & Military sciences & & & $* 0.6844$ & 0.2780 \\
\hline & $\begin{array}{l}\text { Psychology security } \\
\text { MIS }\end{array}$ & & & & $0.4064-$ \\
\hline \multirow[t]{3}{*}{ Total score } & Police sciences & & 0.1356 & *0.9912 & 0.2833 \\
\hline & Military sciences & & & $* 0.8556$ & 0.1477 \\
\hline & $\begin{array}{l}\text { Psychology security } \\
\text { MIS }\end{array}$ & & & & 0.7079- \\
\hline
\end{tabular}

*significant at ( $\alpha=0.05)$.

Tables above show that there are significant differences at $(\alpha=0.05)$ on the first domain due to the major variable in favor of Military Sciences and MIS over Psychology Security.

This result indicates that AU cadets rated themselves EFL skills as they really need them. Taking into account the nature of military sciences courses and staff courses they may pursue postgraduation, most military academies the cadets may enroll are English speaking countries. The same applies to the MIS since most of the computer courses are instructed in English and the textbooks are also international MIS courses. This result is due to the cadets' understanding of the EFL level to be developed. Taking into consideration the focus of the English courses that the cadets had while they were students at public schools, it is possible to conclude that this relative difficulty with speaking is a result of reading and grammar were dominating the syllabus, while speaking and listening were almost neglected.

Police Sciences and MIS found to have significant differences at $(\alpha=0.05)$ on the second domain due to the major variable over Psychology Security. This result shows that all police sciences cadets indicated that speaking skill and listening skill are the most important language to their future work. Cadets indicated that they need to develop their listening skill so as to understand foreigners. Such ranking as the most important skills to their work is consistent with previous findings in ESP which generally indicated that the communicative and functional aspect of English suit ESP courses (Hutchinson \& Waters, 1987; Munby, 1978; Widdowson, 1987).

There are significant differences on the sixth domain in favor of Military Sciences and Police Sciences over Psychology Security. Some cadets indicated that they need writing to write reports related to their job. Other cadets reported that writing is important because they need it to correctly write an article in a security related journal or magazine, or topics when doing a staff course. The researcher elaborated that military forces today are increasingly deployed on humanitarian assistance and peace operations. Different nations contribute to peacekeeping forces, trainings or joint operations and these different national contingents come under a central command or headquarters. Often English is the operational language of this mission. English is the official language that different national contingents use to talk to each and to communicate. Increasingly, the armed forces of different nations work and train together. When soldiers, officers, go on exercise they need to communicate in a common language, and English has 
become a military lingua franca. It is clear that cadets at AU are aware of such need especially Police and Military sciences, especially those who wish to pursue their commission or staff i.e., at Sand Hurst in the UK. This result confirms with Preechawat (2010). On the other hand, Akyel and Yalcin (1991) showed that the policemen reported that listening and speaking are more important than writing to their jobs. Military Sciences and MIS were found to have significant differences at $(\alpha=0.05)$ on the seventh domain over Psychology Security. Again, this result emphasizes the potential role that English language structures may function in the official missions, writings, communications that cadets may need in the future. Also, due to the nature of cadets' courses who study Military Sciences and MIS, they implement and use English more frequently than Psychology Security. The importance of English in promotion and performance domain has also significant differences due to the major variable the differences are in favor of Police, MIS and Military Sciences over Psychology Security. The results showed that cadets need English in order to perform their future jobs more efficiently. The results agree with Al-Gorashi's (1989). There are also significant differences at $(\alpha=0.05)$ on the tenth domain and the total score in favor of Police Sciences and Military Sciences over Psychology Security. The results of the above table show the cadets' responses to security tasks for which cadets were asked to select if they were applicable to their future missions. The cadets' scores ranged from 4.00 to 3.41. The majority of the cadets stated that English is most needed in situations and activities relevant to security work in which they are required to obtain data about the passport holder identity, discussing issues related to arrival and departure of foreigners from the official viewpoint and able to converse with those seeking help in traffic events and problems and offering assistance. Moreover, it was inferred that communicative competence is a potential to address such needs. Such findings confirm with Zhao (2012). The results showed support for the claim in ESP that language materials should be authentic, that is, the materials should be drawn from the learners' area of study or work Alastal and Shuib (2012), Diocesano-Ávila and Salamanca (2012) Brunton(2009), Gatehouse (2001) Hutchinson \& Waters (1987) Munby (1978), Widdowson (1987), Zohrabi (2011). ESP learners are different from those learners' in general English classes in that they are aware of what they need English for. The cadets expressed their need to have materials that include real life situations.

\section{CONCLUSION AND RECOMMENDATION}

In the light of the study results, it is very obvious that cadets feel of a great need to master the English language four skills. This is because they recognize the international use of English language as it became the lingua franca of security cooperation, peacekeeping and joint international operations. If an ESP course is to be designed so as to meet English language cadets needs, stakeholders at Al Istiqlal University should integrate the four language skills focusing on listening and speaking since they had the priority of importance as perceived by cadets.

Further studies on cadets' needs should be pursued to meet the various and constantly changing demands of security sectors especially with the global changes of security men duties.

\section{REFERENCES}

[1] Abdel Ghany S., Y. and Abdel Latif, M., M. (2012). English language preparation of tourism and hospitality undergraduates in Egypt: Does it meet their future workplace requirements? Journal of Hospitality, Leisure, Sport \& Tourism Education 11: 93 -100 . Retrieved January 6, 2013 from www.elsevier.com/locate/jhlste.

[2] Abo Mosallem, E. (1984). English for police officers in Egypt. English for Specific Purposes, 3, 171-182.

[3] Abu-Zahra, M., \& Shayeb, A.S. (2011). Is ESP a need? Birzeit public administration students as a case study. Improving TEFL Methods \& Practices at Palestinian Universities. Retrieved December 3, 2012, from http://www.qou.edu/english/conferences/firstNationalConference.

[4] Akyel, A. and Yalcin, E. (1991). Principles Involved in Writing an ESP Textbook for Turkish Policemen. Journal of Human Sciences, 10(2), 1-25.

[5] Akyela A. S. and Ozeka, Y. (2010). A language needs analysis research at an English medium university in Turkey. Procedia Social and Behavioral Sciences, 2(2), 969-975.

[6] Alastal, A. and Shuib, M. (2012). Investigating the Academic English Language Target Needs of Undergraduates at the Faculty of Applied Science at Al-Aqsa University: Students' Perceptions. The Asian ESP Journal, 8(2): 5-26.

[7] Al-Gorashi, A., K. (1989). The English communication needs of military cadets in Saudi Arabia as perceived by junior officers in the Saudi Army and Air Defense. Unpublished doctoral dissertation. Indiana University Bloomington. Retrieved January 1 , 2013, from http://www.darahlibrary.org.sa/ipac20/ipac.jsp?session=1347605DC18M0.241112.

[8] Al-Huneidi, A. and Bastrurkmen, H. (1996). The Language Needs Analysis Project at the College of Petroleum and Engineering. Retrieved from Eric Database (ED413762).

[9] Alhuqbani M. N. (2008). Identifying the English Language Needs of Saudi Police Officers. Journal of the Saudi Association of Languages and Translation, 1(2), 55-97.

[10] Ali, H., I., H. \& Salih, A., A.(2013). Perceived views of language teachers on the use of needs analysis in ESP materials writing. English Language Teaching, 6(3): 11-19.

[11] Al-Jurf, R. (1994). An ESP program model for graduate students at King Saud University based on academic and occupational needs. King Saud University Journal of Education and Islamic Science, 6 (1), 67-95.

[12] Al-Tamimi A. S. \& Shuib M. (2010). Investigating the English Language Needs of Petroleum Engineering Students at Hadhramout University of Science and Technology. The Asian ESP Journal. 6(1), 1-30.

[13] Basturkmen, H. (2006). Ideas and Options in ESP. Roultedge. London. 
[14] Bedjaoui, F. and Allal, R. (2012). ESP Syllabus Design: A Must for EFL Students. The IUP Journal of English Studies, VI (4): $41-46$.

[15] Benesch, S. (1996). Needs analysis and curriculum development in EAP: An example of a critical approach. TESOL Quarterly, 30, 723-73

[16] Bosher, S., \& Smalkoski, K. (2002). From needs analysis to curriculum development: Designing a course in health-care communication for immigrant students in the USA. English for Specific Purposes, 21, 59-79.

[17] Brown, J. (1995). The Elements of Language Curriculum. A Systematic Approach to Program Development. New York: Heinle \& Heinle Publishers.

[18] Brunton, M. (2009). An account of ESP - with possible future directions. English for Specific Purposes Issue, $3(24)$, Vol. 8. Retrieved November 17, 2012 from http://www.esp-world.info/Articles_24/An\%20account\%20of\%20ESP.pdf.

[19] Chan, V. (2001). Determining students' language needs in a tertiary setting. English Teaching Forum 39(3): 10-18.

[20] Chaudron, C., Doughty, C., Kim, Y., Kong, D. Lee, J., Lee, Y., Long, M., Rivers, R., \& Urano, K. (2005). A task-based needs analysis of a tertiary Korean as a foreign language program. In M. Long. (Ed.), Second language needs analysis (pp. 225-261). Cambridge: Cambridg University.

[21] Chen W.D. (2009). A Pilot Study of Some ROCMA Cadets' Difficulties in English Speaking. WHAMPOA - An Interdisciplinary Journal, 57, 119-126.

[22] Chostelidou, D. (2010). A needs analysis approach to ESP syllabus design in Greek tertiary education: A descriptive account of students' needs. Procedia - Social and Behavioral Sciences, 2(2): 4507-4512.

[23] Cowling, J. D. (2007). Needs analysis: Planning a syllabus for a series of intensive workplace courses at a leading Japanese company. English for Specific Purposes, 26, 426-442.

[24] Diocesano-Ávila C. and Salamanca U. (2012). Use of authentic materials in ESP classroom. Retrieved from Eric Database (ED530013).

[25] Dooey, P. (2006). Identifying the listening and speaking needs of international students. In Experience of learning. Proceedings of the 15th Annual Teaching Learning Forum, 1-2 February 2006. Perth: The University of Western Australia. Retrieved from http://lsn.curtin.edu.au/tlf/tlf2006/refereed/dooey.html.

[26] Dudley-Evans, T. (1998). Developments in English for Specific Purposes: A multi-disciplinary approach. Cambridge: CUP.

[27] Gatehouse, K. (2001). Key issues in English for specific purposes (ESP) curriculum development. The Internet TESOL Journal. Retrieved July 4, 2012 from http://iteslj.org/Articles/Gatehouse-ESP.html.

[28] Hutchinson, T \& Waters, A. (1987). English for specific purposes: A learning centered approach. Cambridge: CUP.

[29] Idris, N., Cheong,L., Nor, N., Razak, A., Z., and Saad, R., M.(2007). The professional preparation of Malaysian teachers in the implementation of teaching and learning of Mathematics and Science in English. EURASIA Journal of Mathematics, Science and Technology Education 3(2): 101-110.

[30] Igawa, K. (2007). Issues in English language education at Korean elementary schools. Bulletin of Shitennoji Kyoto University, 219-236.

[31] Ketkaew, M. (1997). A Survey of Cabin Attendants' Needs of English. Master thesis M.A. (Teaching). Bangkok: Graduate School Kasetsart University. Retrieved June 3, 2013 from http://thesis.swu.ac.th/swuthesis/Bus_Eng_Int_Com/Piamsak_U.pdf.

[32] Khamkaew, S. (2009). Needs and problems in English listening and speaking skills: a case study of metropolitan police officers at counter service at Chana Songkram police station. Retrieved January 2, 2013 from http://thesis.swu.ac.th/swuthesis/Bus_Eng_Int_Com/Suthee_K.pdf.

[33] Khushi Q. and Talaat M. (2011). Evaluation of the English Language Teaching (ELT) Textbooks Taught at the Pakistan Military Academy, Kakul. Language in India, 11, (75-88).

[34] Khushi Q. (2012). Language Skills of PMA Cadets: Insights into Perceptions, Pakistaniaat: A Journal of Pakistan Studies 4(3), 175-188.

[35] Kusumoto, Y. (2008). Needs analysis: developing a teacher training program for elementary school homeroom teachers in Japan. Second Language Studies, 26(2), 1-44.

[36] Lockwood, J. (2012). Developing an English for specific purpose curriculum for Asian call centers: How theory can inform practice. English for Specific Purposes Journal, 31. Retrieved 6 January 2013 from www.elsevier.com/locate/esp.

[37] Long, M. (2005). A rationale for needs analysis research. In M. H. Long (Ed.), Second language needs analysis (pp. 1-18). Cambridge: CUP.

[38] Mackay, R. \& Mountford, A. (Eds.) (1978). English for Specific Purposes: A Case Study Approach. London: Longman.

[39] Martinez-Pons, M. (2001). The psychology of teaching and learning: A three step approach. London: Continuum.

[40] Munby, J. (1978). Communicative syllabus design. London: Cambridge University Press.

[41] Richards, J. C., Platt, J., \& Platt, H. (1992). Dictionary of language teaching and applied linguistics. Malaysia: Longman.

[42] Richards, J.C. (2001). Curriculum development in language teaching. Cambridge: Cambridge University Press.

[43] Robinson, P. (1991). ESP today: A practitioner's guide. New York: Prentice Hall.

[44] Robinson, P. (1980). ESP (English for Specific Purposes): the present position. Oxford: Pergamum Press.

[45] Singh, R. K. (2005). Teaching English for Specific Purposes: An evolving Experience, Jaipur: Book Enclave.

[46] Soruc, A. (2012). The role of needs analysis in language program renewal process. Mevlana International Journal of Education (MIJE), 2(1), 36-47 retrieved January 16, 2013 from http://mije.mevlana.edu.tr/.

[47] Spence, P. and Liu, G. (2013). Engineering English and the high-tech industry: A case study of an English needs analysis of process integration engineers at a semiconductor manufacturing company in Taiwan, English for Specific Purposes, 32( 2): $97-$ 110.

[48] Strevens, P. (1988). ESP after Twenty Years: Are- appraisal. In M. Tickoo (Ed.) ESP: State of the Art. Singapore. SEAMEO Regional Centre, 1-13.

[49] Suwanla-Ong, N. (1999). English language use and language problems of Thai postgraduate students in foreign countries. Unpublished Master's Thesis, The National Institute of Development Administration, Bangkok, Thailand. Retrieved 5 September, 2012 from lc.nida.ac.th/isseminar2011/titiya.pdf. 
[50] Tsao, C. H. (2011). English for Specific Purposes in the EFL Context: A Survey of Student and Faculty Perceptions. Asian ESP Journal 7(2), 126-149.

[51] Valdez, M. G. (1999). How learners' needs affect syllabus design. English Teaching Forum, 37(1), 1-8.

[52] Zhao, Z. (2012). A Study of Inter-cultural Communicative Competence Education for Cadets in Jimei University. Unpublished Master Theses. Retrieved January, 9, 2013 from http://www.p-papers.com/60713.html.

[53] Zohrabi, M. (2011). An Evaluation of the Needs Analysis Component in an Academic Setting. The Asian ESP Journal, 7(4): 153-182 Retrieved November 21, 2012 from http://asian-esp-journal.com/Volume-7-4.pdf.

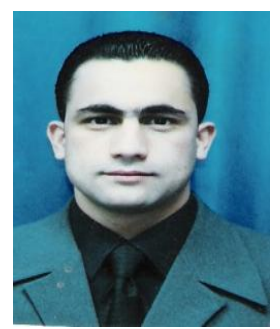

Hussam Ahmed Qaddomi, born in Palestine on April 11, 1977. M.A.(honor) in TEFL from An Najah National University, Nablus, Palestine in 2001 and PhD (honor) degree in Curriculum and EFL Methodology from Cairo University, Egypt in 2010. He has taught for 12 years at many Palestinian universities.

He is currently an Assistant Professor. He had published a number of researches as (i) Qaddomi, H. (2007). Determining English language teachers' attitudes toward using the mother tongue in EFL classroom. Journal of Al-Quds Open University For Research and Studies, 10, 1-31. (ii) Qaddomi, H. (2010). The Influence of Selected Demographic Variables on Hardiness of EFL Teachers in Palestine, Journal of Al-Quds Open University For Research and Studies 25(1), 1-32. (iii) Qaddomi, H. (2013). Investigating Al -Quds Open University Students' EFL Learning Anxiety, An-Najah University Journal for Research - Humanities - 27(5), 2013.

His basic research interests are language learning and language acquisition, cooperative learning, language learning anxiety, motivation and attitudes, and TPRS.

Dr. Qaddomi is currently the Head of Curricula Department / Al Istiqlal University / Jericho / Palestine. 